\title{
In vitro screening of ten Combretaceae plants for antimalarial activities applying the inhibition of beta-hematin formation
}

\author{
Oluyemi M.WANDE and Samuel B. BABATUNDE*
}

Pharmaceutical Chemistry Department, Faculty of Pharmacy, University of Ibadan, Ibadan, Nigeria. *Corresponding author; E-mail: tundebsamuel@gmail.com

\section{ACKNOWLEDGEMENTS}

The authors acknowledge the support of Association of African Universities (AAU) through the research grant (Ref. PC/6) awarded to Oluyemi WM.

\begin{abstract}
The identification of novel molecules for the development of more effective and safe treatments to fight malaria is urgently needed. Medicinal plants are one of the main opportunities in the discovery of such new molecules. Combretaceae is a family members of which have been reported with broad spectrum of bioactivities against different diseases including malaria. The aim of this study was to screen a number Combretaceae plants, selected based on the use in ethnomedicine, for antimalarial activity. Methanolic and acetone extracts of leaves of ten different Combretaceae were screened by applying the inhibition of $\beta$-hematin synthesis, a simple and robust colorimetric assay. The analysis was conducted using a 96-well UV-vis plate reader and the absorbance was read at $405 \mathrm{~nm}$. The $\mathrm{IC}_{50}$ was calculated by analyzing the dose-response data using Graphpad Prism® (6.0). Preliminary results showed that eight plant extracts at $25 \mathrm{mg} / \mathrm{mL}$ demonstrated appreciable activity by inhibiting the formation of hemozoin. The best inhibitory concentration $\left(\mathrm{IC}_{50} 2.58 \pm\right.$ $0.447 \mathrm{mg} / \mathrm{mL}$ ) was observed in Terminalia ivorensis methanol extract (TIM) which was comparable with chloroquine standard drug ( $\mathrm{IC}_{50} 0.55 \pm 0.179 \mathrm{mg} / \mathrm{mL}$ ). Moreover, the Terminalia ivorensis methanol extract showed statistically significant activity $(\mathrm{P}<0.05)$ at the different concentrations used, comparable to chloroquine. Activities studies of the investigated plants confirm the ethnomedicinal use of Terminalia ivorensis in the treatment of malaria. A bioassay-guided fractionation of the leaf extract of the T. ivorensis is ongoing.

(C) 2017 International Formulae Group. All rights reserved.
\end{abstract}

Keywords: Combretaceae, antimalarial, $\beta$-hematin inhibition, Terminalia ivorensis.

\section{INTRODUCTION}

Malaria is due to blood infection by protozoa parasites of the genus Plasmodium, which is transmitted from one human to another by female Anopheles mosquitoes. Nigeria currently holds the largest share of the world's burden of malaria, with an estimated
300,000 deaths annually (RBM, 2008). A key factor contributing to the increasing malaria mortality and morbidity in Africa is the widespread resistance of $P$. falciparum to conventional antimalarial drugs that looks likely to extend to artemisinin combined therapies in the future (Fidock et al., 2004; 
White 2004; WHO, 2000-2010; Dondorp et al., 2009).

From the biological sciences point of view, the intraerythrocytic stage appears to be a very important part of the plasmodium life cycle in the human body. It involves digestion of hemoglobin which provides amino acids and energy both essential for parasite development and proliferation (Francis et al., 1997). To overcome free heme $\left(\mathrm{Fe}^{+3}\right)$ toxicity, malaria parasite is equipped with the unique heme detoxification protein disulfide isomerase (Harwaldt et al., 2002, Campanale et al., 2003). Most important among the heme detoxification mechanisms possessed by malaria parasite is the hemozoin ( $\beta$-hematin) formation (Slater and Cerami, 1992; Ziegler et al., 2001) in the food vacuole of the parasite (Sherman, 1998). This biosynthetic pathway used for the hemozoin ( $\beta$-hematin) formation was previously shown to be inhibited by antimalarial drugs from the 4-aminoquinoline family (Sullivan, 2002; Chong and Sullivan, 2003; Ncokazi and Egan, 2005). These observations have been used to develop a simple and rapid colorimetric (Phi-b assay) based on differential solubilisation and coordination of $\mathrm{Fe}(\mathrm{III})$ PPIX by aqueous pyridine (Py-Fe(III)PPIX) (Ncokazi and Egan, 2005). In the presence of an inhibitor, the synthesis of $\beta$-hematin slows down or even stops and the addition of a buffered pyridine solution in HEPES allows for the selective distinguishing of the synthetic product from hematin. The complex PyFe(III)PPIX displays a red coloration and is detectable by spectroscopy UV-vis with a maximum of absorption of $404 \mathrm{~nm}$. The affinity of pyridine to form a complex with the central iron of a porphyrine forms the basis of this technique, which is used for the quantification of heme (Ncokazi and Egan, 2005).

Natural products continue to play a major role in drug discovery and development, and medicinal plants have been a rich source of many compounds with large production of bioactive molecules (Butler, 2004; Santos et al., 2011). Therefore, the next generation antimalarials or the scaffolds necessary for their synthesis may be found in plants currently used in African traditional medicine against malaria (Hostettmann et al., 2000; Efange, 2002).

This study is based on the broad spectrum of activities generated from the bioprospect of Combretaceae species as widely reported in literature for the treatment of inflammation, cancer, urinary infections, bacterial infections, heart diseases, skin diseases, malaria among several others (Tan et al., 2002). Combretaceae family comprises species of trees, shrubs and lianas, with distribution in tropical and subtropical regions and is widely used for medicinal purposes in Africa, Asia, South America and India (Pettit et al., 1987; Tan et al., 2002). Ethnomedicinal use of different species of the genera Combretum and Terminalia has been widely reported in literature for antimalarial potential (Clarkson et al., 2004; Atindehou et al., 2004; Ngemenya et al., 2004; Gedson et al., 2012; Cock, 2015). The current study investigated some species of the Combretaceae family for their antimalarial activities.

\section{MATERIALS AND METHODS Plant collection}

Ten Combretaceae plants (eight Combretum and two Terminalia species) were collected and identified by the Curator of the Botanical garden, University of Ibadan, Nigeria. Voucher specimens are deposited at the Forest Research Institute of Nigeria (FRIN), Ibadan Herbarium.

\section{Plant extraction}

The leaves of the ten plants were air dried and ground to powder. Fifty grams (50 g) each of the powdered plant were extracted independently with acetone and methanol using Soxhlet apparatus. Eighteen extracts 
were tested. The extracts were filtered, concentrated and stored in the refrigerator till needed for analysis.

\section{Reagents and equipments}

Bovine hemin, hydroxyethylpiperazine$\mathrm{N}$-[2-ethanesulfonic acid] (HEPES), pyridine anhydrous $99.8 \%$, sodium acetate, glacial acetic acid, hydrochloric acid $(\mathrm{HCl})$, sodium hydroxide $(\mathrm{NaOH})$ were all purchased from Sigma-Aldrich.

\section{Beta-hematin inhibition assay}

The ability of the extracts to inhibit the formation of beta-hematin in vitro was determined using the method of Vargas et al. (2011).

\section{Preparation of solutions}

A stock concentration of the plant extracts was prepared by dissolving $500 \mathrm{mg}$ of each of the acetone and methanol extracts in $10 \mathrm{~mL}$ of acetone and methanol respectively to make $50 \mathrm{mg} / \mathrm{mL}$. Fresh bovine hematin solution $(0.68 \mathrm{mg} / \mathrm{mL})$ was prepared by dissolving $6.8 \mathrm{mg}$ of bovine hemin in $10 \mathrm{~mL}$ of $0.1 \mathrm{M} \mathrm{NaOH}$ for each determination. HEPES solution $(4.76 \mathrm{mg} / \mathrm{mL})$ was prepared by dissolving $238 \mathrm{mg}$ of HEPES in $50 \mathrm{~mL}$ of distilled water and its $\mathrm{pH}$ adjusted to 7.5. Fifteen percent of pyridine (15\%) used for the assay was prepared by adding $15 \mathrm{~mL}$ of pyridine into $85 \mathrm{~mL}$ of HEPES solution. Saturated acetate solution was prepared by dissolving $36 \mathrm{~g}$ of sodium acetate in $20 \mathrm{~mL}$ of distilled water and $48 \mathrm{~mL}$ of acetic acid, and then pre-warmed at $60{ }^{\circ} \mathrm{C}$ before each use.

\section{Qualitative determination of inhibition beta-hematin formation}

$25 \mathrm{mg} / \mathrm{mL}$ concentration of each of the ten plant extracts were tested in the betahematin synthesis inhibition. Briefly, $10 \mu \mathrm{L}$ of each of the plant extract and chloroquine was dispensed into wells in columns of 96-well plates and were tested. Furthermore, $10 \mu \mathrm{L}$ of
$1 \mathrm{M} \mathrm{HCl}$ was added to all plant extracts in the 96-well plates. Into the wells in row A and B $100 \mu \mathrm{L}$ of freshly prepared hematin solution was added. The test plate was shaken at 900 rpm for 10 minutes. This was followed by addition of $60 \mu \mathrm{L}$ of saturated acetate solution (pH 5.0), pre-warmed at $60{ }^{\circ} \mathrm{C}$ to all the wells. The test plate was further incubated at $60{ }^{\circ} \mathrm{C}$ for 90 minutes. Thereafter, $750 \mu \mathrm{L}$ of $15 \%$ pyridine was added to wells in the row $\mathrm{A}$ and $\mathrm{C}$ while $750 \mu \mathrm{L}$ HEPES (pH 7.5) was added to wells in row B and D. Thereafter, the test plate was shaken at $900 \mathrm{rpm}$ for 10 minutes and allowed to settle for 15 minutes. An aliquot of $100 \mu \mathrm{L}$ was transferred in triplicate to a non-sterilized 96-well plate. The absorbance was measured at $405 \mathrm{~nm}$ with a Rayto scientific RT-6100 microplate reader.

\section{Determination of the inhibition of beta- hematin}

The inhibition of the beta-hematin synthesis was determined according to the process described below. For each sample tested, there was a control analysis $\left(\mathrm{A}_{\text {Analysis;Blank }}\right)$ which differed from the sample submitted for the analysis ( $\mathrm{A}_{\text {Analysis }}$ ) by the addition of $750 \mu \mathrm{L}$ of HEPES $(4.76 \mathrm{mg} / \mathrm{mL})$ instead of pyridine, after incubation. Also, for each tested sample, a blank control ( $\mathrm{A}_{\mathrm{CLT} ; \mathrm{Blank}}$ ) as well as its blank ( $\mathrm{A}_{\mathrm{CLTBlank} \text {;Blank }}$ ) were prepared in the absence of hematin but with $750 \mu \mathrm{L}$ of $15 \%$ pyridine or $750 \mu \mathrm{L}$ of HEPES. The residual absorbance $\left(\Delta \mathrm{A}_{\text {Analysis }}\right)$ of the sample due to inhibition of $\beta$-hematin was calculated using the following formula:

$\Delta \mathrm{A}_{\text {Analysis }}=\mathrm{A}_{\text {Analysis }}-\mathrm{A}_{\text {Analysis;Blank }}$

The residual absorbance $\left(\Delta \mathrm{A}_{\mathrm{CLT} ; \mathrm{Blank}}\right)$ of the sample independent from the inhibition of the $\beta$-hematin complex was calculated using the following formula:

$\Delta \mathrm{A}_{\mathrm{CLT} ; \text { Blank }}=\mathrm{A}_{\mathrm{CLT} ; \text { Blank }}-\mathrm{A}_{\mathrm{CLTBlank} ; \text { Blank }}$

The resulting inhibition of the $\beta$ hematin synthesis induced by the analyzed sample was calculated using the following formula: 
$\mathrm{I}_{\text {Analysis }}=\Delta \mathrm{A}_{\text {Analysis }}-\Delta \mathrm{A}_{\mathrm{CLT} ; \text { Blank }}$

If $\mathrm{I}_{\text {Analysis }}$ has a positive value, the assay is considered as positive (active sample) whereas a negative value indicated a negative result.

\section{Quantitative determination of $\mathbf{5 0 \%}$ inhibitory concentration $\left(\mathrm{IC}_{50}\right)$}

The above experiment was repeated for six other concentrations (12.5 to $0.39 \mathrm{mg} / \mathrm{mL}$ ) in seven prominently active extracts tested and chloroquine. The extracts and chloroquine were tested in triplicates in 96-well plates. $\mathrm{IC}_{50}$ values were determined using non-linear regression in a commercially available statistical package Prism Graphpad® (6.0).

\section{Statistical analysis}

Results were expressed as means \pm SEM and analyzed using prism Graphpad ${ }^{\circledR}$ (6.0). Comparisons were made between positive control (chloroquine) and treatment groups of various concentrations using oneway analysis of variance (ANOVA) followed by Tukey's multiple comparison tests. The mean $\mathrm{IC}_{50}$ values obtained for the extracts were compared with the $\mathrm{IC}_{50}$ value obtained for chloroquine using paired t-test. P-values of 0.05 were considered statistically significant.

\section{RESULTS}

The result of the qualitative determination of antimalarial activity of the plant extracts from members of the Combretaceae family by the inhibition of $\beta$ hematin formation is shown in Table 1. Both extracts of two of the medicinal plants tested (Combretum confertum and Terminalia mentalis) showed no activity at the concentration $25 \mathrm{mg} / \mathrm{ml}$ used. The Terminalia ivorensis methanol extract was more active than the acetone extract. Only Combretum racemosum showed the same degree of activity for both extracts. Chloroquine tested at $10 \mathrm{mg} / \mathrm{ml}$ showed activity, but out of the eighteen extracts tested in this assay, six $(C$. platypterum, $C$. hispidum, $C$. racemosum, $C$. sordidum acetone extracts and $C$. racemosum, T. ivorensis methanol extracts) showed higher activity than chloroquine.

The result of the quantitative determination of inhibition of $\beta$-hematin formation at different concentrations is presented in Figure 1. Terminalia ivorensis methanol extract (TIM) had the significantly highest inhibition at all concentrations compared with other plant extracts. Its inhibition was also higher than that of chloroquine even at the lowest concentration $(0.39 \mathrm{mg} / \mathrm{mL})$. Combretum zenkeri and Combretum racemosum methanol extracts (CZM and CRM) had medium activity but the activity was significant in comparison with chloroquine by two-way ANOVA post analysis Tukey's comparison.

The results of the $\mathrm{IC}_{50}$ values and $\mathrm{P}$ values measured, which show how effective the extracts are, are shown in Table 2. As shown in Table 2 and Figure 1, in the quantitative testing of $\beta$-hematin formation inhibition at different concentrations, CPLA, CHA, CRA and CSA had no antimalarial activity while CZM, CRM and TIM showed appreciable antimalarial activity. CZM, TIM and CRM showed highly significant antimalarial activity $\left(\mathrm{IC}_{50}=2.92 \pm 0.846\right.$ $\mathrm{mg} / \mathrm{ml}, \mathrm{IC}_{50}=2.58 \pm 0.447 \mathrm{mg} / \mathrm{ml}$ and $\mathrm{IC}_{50}=$ $3.96 \pm 0.132 \mathrm{mg} / \mathrm{ml}$ respectively) comparable to the standard antimalarial compound, chloroquine $\left(\mathrm{IC}_{50}=0.77 \mathrm{mg} / \mathrm{ml}\right.$ ). But only TIM was not significantly different when compared with chloroquine using the one-way ANOVA post analysis Tukey's comparison. Generally in this study, TIM ( $\mathrm{IC}_{50}=2.58 \pm$ $0.447 \mathrm{mg} / \mathrm{ml}$ ) demonstrated remarkable the most pronounced effect among all the extracts tested. 
Table 1: Results of Antimalarial $\beta$-hematin synthesis inhibition at $25 \mathrm{mg} / \mathrm{mL}$ of plant extracts, IAnalysis $>0$ is active and \% yield in solvent of extraction.

\begin{tabular}{lllll}
\hline \multirow{2}{*}{ Samples } & \multicolumn{3}{c}{ Extraction solvent } & \multicolumn{2}{c}{ \% yield } \\
\cline { 2 - 5 } & Acetone & Methanol & Acetone & Methanol \\
\hline C. confertum & - & - & 8.4 & 6.2 \\
C. zenkeri & - & ++ & 19.1 & 17.4 \\
C. platypterum & +++ & - & 9.5 & 7.3 \\
C. hispidum & +++ & - & 3.3 & 2.7 \\
C. racemosum & +++ & +++ & 12.5 & 10.9 \\
C. paniculatum & + & - & 4 & 2.9 \\
C. sordidum & +++ & $\mathrm{NT}$ & 7.22 & NA \\
C. dolicopetalum & ++ & $\mathrm{NT}$ & 7.34 & NA \\
T. mentalis & - & - & 7.3 & 5.1 \\
T. ivorensis & ++ & +++ & 12.5 & 8 \\
Chloroquine & ++ & & & \\
(10 mg/mL) & & & & \\
\hline
\end{tabular}

+++ = High activity, ++ = Moderate activity, + = Low activity, - = No activity, NT = Not Tested, NA = Not Available.

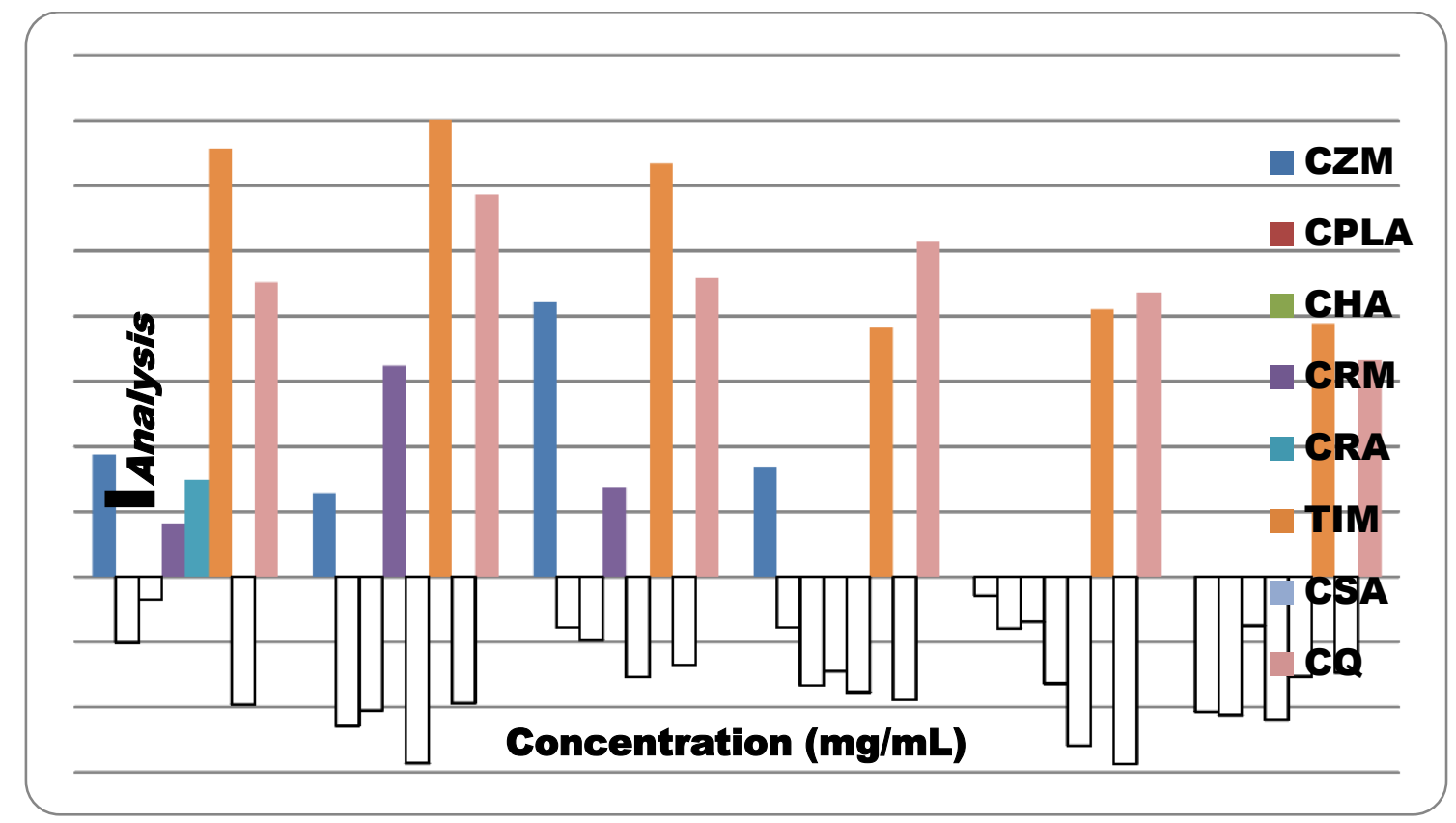

Figure 1: The inhibition of $\beta$-hematin formation at different concentrations determined spectrophotomically at $405 \mathrm{~nm} . \mathrm{CZM}=C$. zenkeri methanol extract, $\mathrm{CPLA}=C$. platypterum acetone extract, $\mathrm{CHA}$ $=C$. hispidum acetone extract, $\mathrm{CRM}=C$. racemosum methanol extract, $\mathrm{CRA}=C$. racemosum acetone extract, $\mathrm{TIM}=T$. ivorensis methanol extract, $\mathrm{CSA}=C$. sordidum acetone extract, $\mathrm{CQ}=$ Chloroquine. 
Table 2: $\mathrm{IC}_{50}$ determination of $\beta$-hematin formation inhibition and $\mathrm{p}$-value of $\mathrm{T}$-test comparison against the standard compound chloroquine.

\begin{tabular}{lcc}
\hline Extract & $\begin{array}{c}\mathbf{I C}_{\mathbf{5 0}} \mathbf{m g} \mathbf{\text { ml }} \\
\text { Mean } \mathbf{\text { SEM }}\end{array}$ & T-test P value \\
\hline CZM & $2.92 \pm 0.846$ & 0.0514 \\
CPLA & $* *$ & $* *$ \\
CHA & $* *$ & $* *$ \\
CRM & $3.96 \pm 0.132$ & 0.0081 \\
CRA & $* *$ & $* *$ \\
TIM & $2.58 \pm 0.447$ & 0.0736 \\
CSA & $* *$ & $* *$ \\
CQ & $0.55 \pm 0.179$ & \\
\hline
\end{tabular}

Experiment was performed in triplicate and expressed as Mean $\pm \mathrm{SEM}$, ** No effect

$\mathrm{CZM}=C$. zenkeri methanol extract, $\mathrm{CPLA}=C$. platypterum acetone extract, $\mathrm{CHA}=C$. hispidum acetone extract, $\mathrm{CRM}=$ $C$. racemosum methanol extract, $\mathrm{CRA}=C$. racemosum acetone extract, $\mathrm{TIM}=T$. ivorensis methanol extract, $\mathrm{CSA}=C$. sordidum acetone extract, $\mathrm{CQ}=$ Chloroquine.

\section{DISCUSSION}

Antimalarial activities of different medicinal plants using the in vitro inhibition of $\beta$-hematin (hemozoin) formation has been reported by Vargas et al. (2011). The medicinal plants screened in this study are all from the family of Combretaceae.

Malaria is a disease caused by the parasite of the genus Plasmodium. This parasite ingests more than $75 \%$ of the host hemoglobin during intra-erythrocytic cycle; therefore, substantial amount of heme is generated as a toxic by-product from massive degradation of hemoglobin (Goldberg et al., 1990; Tekwani and Walker, 2005). Subsequently, parasite for protecting itself from the self-produced toxic material has evolved a process for detoxification through the crystallization of heme into an insoluble, nontoxic crystalline pigment known as hemozoin (Mojarrab et al., 2014; Bandyopadhyay and Dey, 2011; Sonnet and Mullie, 2011). Hemozoin is equivalent to $\beta$ hematin, which consists of cyclic heme dimers arranged in an ordered crystalline structure through intermolecular hydrogen bonding. It is believed to be the most validated target of detoxification. From a drug target perspective this pathway has been validated for several antimalarial molecules including the 4aminoquinolines (quinine, mefloquine, amodiaquine and chloroquine) and this is therefore considered a suitable target for drug discovery programs (Dorn et al., 1998; Egan 2003). Many different quantitative in vitro methods based on spectral characteristics and differential solubility of monomeric heme and $\beta$-hematin have been used for evaluation of antimalarial activities (Tekwani and Walker, 2005; Ncokazi and Egan, 2005; Wenzel et al., 2010; Vargas et al., 2011). In this study, eighteen leaf extracts of ten Combretaceae species were evaluated for their antimalarial activities by using an in vitro method. Our findings revealed that the leaf extracts of eight species showed inhibition of the formation of hemozoin ( $\beta$-hematin), which suggests the presence of antimalarial compounds in the leaves. The results showed that extracts with different mode of extraction exhibit different degrees of antimalarial activities as shown in Table 1.

The extraction methods adopted in this study were based on the fact that many of the plants studied are prepared in ethnomedicine by alcoholic decoction (Clarkson et al., 2004; 
Atindehou et al., 2004; Gedson et al., 2012) and solvents of intermediate polarity have been shown to possess the highest extraction capacity for both non-polar and polar constituents of plants (Eloff et al., 2005; Eloff et al., 2011). The result on Table 1 shows that the percentage yield of all the acetone extracts are higher than that of the methanol, which suggests that acetone (intermediate polar solvent) extract more phytocompounds than methanol (polar solvent) which supports the report of Eloff et al. (2005).

The pyridine-hemochrome complex (Py-Fe(III)PPIX) formation was monitored spectrophotometrically at different concentrations. The protocol for the synthesis of $\beta$-hematin was modified from Vargas et al. (2011) to adapt it to the screening of plant extracts as carried out in this present study. The inhibition of $\beta$-hematin formation of an extract is an indicator of its antimalarial potential. A high absorbance value of the sample is an indicator of increased inhibition of the formation of $\beta$-hematin. The inhibition of $\beta$-hematin formation by the extracts is dose independent as shown in Figure 1. Based upon the results presented in Figure 1 and Table 2, among the seven extracts tested for activity using the $\beta$-hematin model, Terminalia ivorensis methanol extract (TIM) was the most potent with an $\mathrm{IC}_{50}$ value of $2.58 \pm 0.447$ $\mathrm{mg} / \mathrm{ml}$. Other polar extracts, Combretum zenkeri (CZM) and Combretum racemosum (CRM) methanol extracts were also determined as significantly potent antimalarial extracts with $\mathrm{IC}_{50}$ values of $2.92 \pm 0.846$ and $3.96 \pm 0.132 \mathrm{mg} / \mathrm{ml}$ respectively. There is little information on the antimalarial activities of these three promising combretaceae.

Cobbinah (2008) reported the presence of saponins, anthraquinone glycosides, steroids, triterpenoids, tannins, flavonoids and polyphenols in various extracts of Terminalia ivorensis. Ujowundu et al. (2010) reported the presence of saponins, alkaloids, flavonoids, tannins and cyanogenic glycosides in the leaves of Combretum zenkeri. Onocha et al. (2005) reported the presence of alkaloids, steroids, cardiac glycosides, saponins and tannins in different extracts of Combretum racemosum. Samuel et al. (2014) in a separate study isolated a flavonoid from the acetone extract of Combretum racemosum. This correlate with some of the identified phytochemicals in some Combretum species as reported by Rodrigues et al. (2012). The presence of alkaloids in these plants confirms the findings of Ajaiyeoba et al. (2006) that the traditional use of the plants for the treatment of malaria was due to the presence of alkaloids. Mfopa et al. (2017) in another study reported the presence of alkaloids in an extract with antimalarial activity. Alshawsh et al. (2007) reported that tannins may have antiplasmodial activity. The cardiac glycosides are used for treating heart problems that may result from severe malaria attack (Fatoba et al., 2003). From phytochemical screening reports, it was deduced that plants containing steroids play a role in the treatment of cerebral malaria, thus these steroids might have contributed to the antiplasmodial activity seen in Terminalia ivorensis and Combretum racemosum (David et al., 2004). Tannins have also been found to be potentially anti-viral, anti-bacterial and anti-parasitic agents (Ene et al., 2008). Dibua et al. (2013) also identified tannins, saponins, terpenoids, steroids, glycosides, proteins, fats and oil, and acidic compounds as possible antimalarial agents in medicinal plants. Also, Vargas et al. (2011) using the $\beta$-hematin model employed in this present study tested the antimalarial activity of some flavonoids, alkaloids and tannins compounds, and found them to be very active comparable to the in vitro Plasmodium falciparum growth inhibition assay (NF54) used by several laboratories as the golden standard in the antimalarial drug screening. Thus, it is plausible to assume that all these secondary metabolites present in these plants could contribute to the high antimalarial activity observed and maybe also in other Combretaceae used traditionally for the treatment of malaria. The results of this study 
confirm the traditional usage of some of these plants as reported in literature (Clarkson et al., 2004; Atindehou et al., 2004; Gedson et al., 2012).

Beta-hematin assay has the merit to be informative; the mechanism of action responsible for their antiplasmodial activity can be assessed (Vargas et al., 2011). Since those inhibitors of the hemozoin formation pathway do not act on a target, but rather interfere with a physicochemical process, they are unlikely to face drug cross resistance issues related to 4-aminoquinolines, particularly chloroquine (Vargas et al., 2011).

Moreover, based on previous research, the presence of lipids and fatty acids in active extracts and fractions showed synergistic effects with oleic acid in assay; therefore, the recorded absorbances were higher than the negative control. It was shown that the $\mathrm{IC}_{50}$ values were reduced by entirely eliminating the fatty acids and purifying the active antimalarial constituents (Afshar et al., 2011; Mojarrab et al., 2014). Ethnopharmacological data has been one of the common useful ways for the discovery of biologically active compounds from plants (Kuria, 2001). Furthermore, the ethnopharmocological informations gathered from this study could allow for some rationalization with respect to the biological potential of the plants used.

\section{Conclusion}

The result of this study showed that Terminalia ivorensis, Combretum racemosum and Combretum zenkeri possess antimalarial activities comparable with chloroquine, which suggests that members of the Combretaceae family could be potent antimalarial agents. This justifies their continuous traditional use as antimalarial remedies. A bio-guided investigation is ongoing in our laboratory to isolate, identify and characterize the active molecule(s) responsible for the observed antimalarial effect from the three Combretaceae species found to be most active in this study.

\section{COMPETING INTERESTS} interest.

The authors declare no competing

\section{AUTHORS' CONTRIBUTIONS}

SBB designed and supervised the study; OMW carried out the chemical and biological aspects of the study and drafted the manuscript; SBB and OMW revised the manuscript. Both authors agreed on the final version of the manuscript.

\section{REFERENCES}

Afshar FH, Delazar A, Janneh O, Nazemiyeh H, Pasdaran A, Nahar L, Sarker SD. 2011. Evaluation of antimalarial, freeradical scavenging and insecticidal activities of Artemisia scoparia and A. spicigera, Asteraceae. Braz J Pharm., 21: $\quad 986-990 . \quad$ http://dx.doi.org/ 10.1590/S0102- 695X2011005000144

Ajaiyeoba E, Falade M, Ogbole O, Okpako L, Akinboye D. 2006. In vivo antimalarial and Cytotoxic properties of Annona senegalensis extract. African Journal of Traditional, Complementary and Alternative Medicine, 3(1): 137 - 141.

Alshawsh MA, Methana RA, Alshamahy HA, Alsllami SF, Lindequist U. 2007. Assessment of Antimalaria Activity against Plasmodium falciparum and phytochemical screening of some Yemeni Medicinal Plants. EvidenceBased Complementary and Alternative Medicine, 6(4): 453 - 456.

Atindehou, KK, Schmid, C, Brun, R, Koné, MW, Traore, D. 2004. Antitrypanosomal and antiplasmodial activity of medicinal plants from Côte d'Ivoire. $J$. Ethnopharmacol., 90: 221-227.

Bandyopadhyay U, Dey S. 2011. Antimalarial drugs and molecules inhibiting hemozoin formation. Apicomplexan Parasites. Mol. Appr. Targ. Drug Develop., 205-234. doi: 10.1002/9783527633883. ch11

Butler MS 2004. The role of natural product chemistry in drug Discovery. J. Nat. Prod., 67(12): 2141 - 2153. 
Campanale N, Nickel C, Daubenberger C A, Wehlan D A, Gorman J J, Klonis N, Becker K, Tilley L. 2003. Identification and characterization of heme interacting proteins in the malaria parasite, Plasmodium falciparum. J. Biol. Chem., 278: 27354-27361.

Chong CR, Sullivan DJ. 2003. Inhibition of heme crystal growth by antimalarials and other compounds: implications for drug discovery. Biochem. Pharm., 66: 22012212.

Clarkson C, Maharaj VJ, Crouch NR, Grace OM, Pillay P, Matsabisa MG, Bhagwandin N, Smith PJ, Folb PI. 2004. In vitro antiplasmodial activity of medicinal plants native to or naturalised in South Africa. J. Ethnopharmacol., 92: 177-191.

Cobbinah EA. 2008. Antioxidant and antibacterial activities of the chemical constituents of Terminalia ivorensis chev., MSc thesis submitted to the department of Chemistry, Kwame Nkrumah University of Science and Technology.

David AF, Phillip JR, Simon LC, Reto B, Solomon N. 2004. Antimalarial drug discovery: Efficacy models for compound screening. Nature, 3: 509520 .

Dibua UM, Okeke CC, Ugwu C, Kenechukwu FC, Okorie A. 2013. In vivo antimalarial and cytotoxicity activity of ethanolic stem bark of Petersianthus macrocarpus and leaf of Astonia boonei in experimental mice model. Int. J. Curr. Microbiol. App. Sci., 2(12): 354-368.

Dondorp AM, Nosten F, Yi P, Das D, Phyo AP, Lwin JTKM, Ariey F, Hanpithakpong W, Lee SJ, Ringwald P, Silamut K, Imwong M, Chotivanich K, Lim P, Herdman T, An SS, Yeung S, Singhasivanon P, Day NPJ, Lindegardh N, Socheat D, White NJ. 2009. Artemisinin resistance in Plasmodium falciparum malaria. N. Engl. J. Med., 361: 455-467.
Dorn A, Vippagunta SR, Matile H, Jaquet C, Vennerstrom JL, Ridley RG. 1998. An assessment of drug-haematin binding as a mechanism for inhibition of haematin polymerization by quinoline antimalarials. Biochem. Pharmaco., $\mathbf{5 5}(6): 727-736$.

Egan TJ. 2003. Haemozoin (malaria pigment): a unique crystalline drug target. Targets, 2(3):115-124.

Efange SMN. 2002. Natural products: a continuing source of inspiration for the medicinal chemist. In Advances in Phytomedicine, Iwu MM, Wootton JC (eds). Elsevier Science: Amsterdam; 6169.

Eloff JN, Famakin JO, Katerere DR. 2005. Isolation of an antibacterial stilbene from combretum woodii (combretaceae) leaves. African Journal of Biotechnology, 4(10): 1167-1171.

Eloff JN. 1998. Which extracts should be used for the screening and isolation of antimicrobial compounds from plants? Journal of Ethnopharmacology, 60:1-8.

Eloff JN, Ntloedibe DT, Brummelen R van 2011. A simplified but effective method for the quality control of medicinal plants by planar chromatography. African Journal of Traditional, Complementary and Alternative Medicine, 8(S): 1-12.

Ene AC, Ameh DA, Kwanashie HO, Agomuo PU, Atawodi SE. 2008. Preliminary in vivo antimalarial screening of petroleum ether, chloroform and methanol extracts of fifteen plants grown in Nigeria. $J$. Pharmacol Toxicol., 32: 254-260.

Fatoba PO, Omojasola PF, Awe S, Ahmed FG. 2003. Phytochemical screening of some selected tropical African Mosses. Nigerian Society for Experimental Biology (NISEB) Journal, 3(2): 49-52.

Fidock DA, Rosenthal PJ, Croft SL, Brun R, Nwaka S. 2004. Antimalarial drug discovery: efficacy models for compound screening. Nature Reviews 
Drug Discovery. 3: 509-520. Doi: 10.1038/nrd1416

Francis SE, Sullivan DJ Jr., Goldberg DE. 1997. Hemoglobin metabolism in the malaria parasite Plasmodium falciparum. Ann. Rev. Microbiol., 51: 97-123.

Fyhrquist P, Mwasumbi L, Haeggstrom CA, Vuorela H, Hiltunen R, Vuorela P. 2002. Microscopic diagnosis of tumors of the central nervous system by phase contrast microscopy. J. Ethnoph., 79: 169-177.

Gedson RM, Igor RP, Marcelo RD, Neyres ZT, Heloina SF, Jose MB, Analucia GS, Augusto LS, Josean FT, Leonia MB. 2012. Bioactivities of the genus Combretum (combretaceae): A Review. Molecules, 17: 9142-9206; DOI: 10.3390/molecules 17089142

Goldberg DE, Slater AFG, Cerami A, Henderson GB. 1990. Hemoglobin degradation in the malaria parasite Plasmodium falciparum: an ordered process in a unique organelle. Proc. Nation Acad. Sci. USA, 87: 2931-35. DOI: 10.1073/pnas.87.8.2931

Harwaldt P, Rahlfs S, Becker K. 2002. Glutathione S-transferase of the malaria parasite Plasmodium falciparum: characterization of a potential drug target. Biol. Chem., 383: 821-830.

Hostettmann K, Marston A, Ndjoko K, Wolfender JL. 2000. The potential of African plants as a source of drugs. Curr Org Chem., 4: 973-1010.

Kuria KAM, De Coster S, Muriuki G, Masengo W, Kibwage I, Hoogmartens J, Laekeman GM. 2001. Antimalarial activity of Ajuga remota Benth (Labiatae) and Caesalpinia volkensii Harms (Caesalpiniaceae): in vitro confirmation of ethnopharmacological use. J. Ethnopharmacol., 74:141-148.

Mfopa AN, Mbouna CDJ, Tchokouaha LRY, Tchuente MAT, Kouipou RMT, Fokou PVT, Kemgne EAM, Kamkumo RG, Boyom FF. 2017. In vitro and in vivo antiplasmodial activity of extracts from Polyalthia suaveolens, Uvaria angolensis and Monodora tenuifolia (Annonaceae). Int. J. Biol. Chem. Sci., 11(1):118-130.

DOI: http://dx.doi.org/10.4314/ijbcs.v11i1.10

Mojarrab M, Shiravand A, Delazar A, Heshmati Afshar F. 2014. Evaluation of in vitro antimalarial activity of different extracts of Artemisia aucheri Boiss. and A. armeniaca $\mathrm{L}$ and fractions of the most potent extracts. Scientific World J., 1-6. DOI: http://dx.doi /10.1155/2014/825370

Ncokazi KK, Egan TJ. 2005. A colorimetric high-throughput $\beta$-hematin inhibition screening assay for use in the search for antimalarial compounds. Anal. Biochem., 338(2): 306-319.

Ncokazi KK, Egan TJ. 2005. Quinoline antimalarials decrease the rate of $[\beta]$ hematin formation, J. Inorg. Biochem., 99: 1532-1539.

Ngemenya MN, Tane P, Berzins K, Titanji VPK. 2004. Antiplasmodial Activity of some Medicinal Plants used in Cameroon:- preliminary toxicity studies of highly active extracts . XIth Annual Conference of The Cameroon Bioscience Society. 16- 18 December, 2004.

Ogan AU. 1972. Alkaloids in leaves of Combretum micranthum. Studies on West African medicinal plants. Planta Med., 21(2):210-217.

Onocha PA, Audu EO, Ekundayo O Dosumu OO. 2005. Phytochemical and Antimicrobial Properties of Extracts of Combretum racemosum. ISHS Acta Horticulturae 675:III WOCMAP Congress on Medicinal and Aromatic Plants - Volume 1: Bioprospecting and Ethnopharmacology. Eds. J. Bernáth, É. Németh, L.E. Craker and Z.E.Gardner. http://www.actahort.org/members/showp df?booknrarnr=675_12

Pettit GR, Singh SB, Niven ML, Hamel E, Schmidt JM. 1987. Isolation, Structure, and Synthesis of Combretastatins A-1 and B-1, Potent New Inhibitors of Microtubule Assembly, Derived from 
Combretum caffrum. J. Nat. Prod., 50(1): 119-131.

Rodrigues I, Naehrer K. 2012. Prevalence of mycotoxins in feedstuffs and feed surveyed worldwide in 2009 and 2010. Phytopath. Medit., 51: 175-192.

Roll back malaria. 2008. Malaria consortium roll back malaria needs assessment report, pp 8-12.

Samuel BB, Owolabi OM, Adaramoye O, Williams E, Jain KS. 2014. Bioguided isolation of an antioxidant compound from Combretum racemosum P.Beav leaf. Int. J. Biol. Chem. Sci., 6(5): 23392346.

DOI: http://dx.doi.org/10.4314/ijbcs.v8i5.36

Santos SN, Oliveira LKX, Melo IS, Velozo ES, Roque MRA. 2011. Antifungal activity of bacterial strains from the rhizosphere of Stachytarpheta crassifólia. Afri. J. Biot., 10(25): 49965000.

Sherman IW. 1998. A brief history of malaria and discovery of the parasite's life cycle. In Malaria: Parasite Biology, Pathogenesis and Protection, Sherman IW (ed). ASM: Washington, DC.

Slater AF, Cerami A. 1992. Inhibition by chloroquine of a novel haem polymerase enzyme activity in malaria trophozoites. Nature, 355: 167-169.

Sonnet P, Mullie C. 2011. In vitro antimalarial activity of ICL670: A further proof of the correlation between inhibition of beta-hematin formation and of peroxidative degradation of hemin. Exp. Parasitol., 128: 26-31. DOI:10.1016/j.exppara.2011.01.018

Sullivan DJ. 2002. Theories on malarial pigment formation and quinoline action. Int. J. Parasitol., 32: 1645-1653.

Tan FX, Shi SH, Zhong Y, Gong X, Wang YG. 2002. Phylogenetic relationships of Combretoideae (Combretaceae) inferred from plastid, nuclear gene and spacer sequences. J. Plant Res., 115: 475-481.

Tasdemir D, Kaiser M, Brun R, Yardley V, Schmidt TJ, Tosun F, Ruedi P. 2006. Antitrypanosomal and antileishmanial activities of flavonoids and their analogues. In vitro, in vivo, structure activity relationship and quantitative structure activity relationship studies, Antimicrob. Agents Chemother., 49: 1352-1364.

Tekwani BL, Walker LA. 2005. Targeting the hemozoin synthesis pathway for new antimalarial drug discovery: technologies for in vitro beta-hematin formation assay. Com. Chem. High T Scr., 8: 6379. DOI: $10.2174 / 1386207053328101$

Trease GE, Evans WC. 1997. Phytochemicals In Pharmacognosy Textbook (4th edn). Harcourt Brace and Company Asia PTE Limited: India; 269 - 275.

Ujowundu CO, Okafor OE, Agha NC, Nwaogu LA, Igwe KO Igwe CU. 2010. Phytochemical and chemical composition of Combretum zenkeri leaves. Journal of Medicinal Plants Research, 4(10): 965-968.

Vargas S, Ndjoko Ioset K, Hay AE, Ioset JR, Wittlin S, Hostettmann K. 2011. Screening medicinal plants for the detection of novel antimalarial products applying the inhibition of $\beta$ hematin formation. Pharm. Biomed. Anal., 56: 880-886.

Wenzel NI, Chavain N, Wang Y, Friebolin W, Maes L, Pradines B, Lanzer M, Yardley V, Brun R, Herold-Mende C, Biot C, Toth K, Davioud-Charvet E. 2010. Antimalarial versus cytotoxic properties of dual drugs derived from 4aminoquinolines and Mannich bases: interaction with DNA. J. Med. Chem., 22: 3214-26. DOI: $10.1021 / \mathrm{jm} 9018383$

White NJ. 2004. Antimalarial drug resistance, J. Clin. Invest., 113: 1084-1092. 